\title{
10-(1-ピレニル) デカン酸の多様な自己会合体
}

\author{
（1986 年 8 月 8 日受理）
}

加釈航治*・浦木久狺・橋本静信

10-(1-ピレニル)デカン酸 (PDA と略す) の水中に和ける会合体について, 监光分光法により検討し た。 pH 5.0 の緩衝溶液中, PDA はミクロクリスタルとして分散し，ヒノマー敩光以外飞, $430 \mathrm{~nm}$ 付 近に構造のある会合体発光を示した。この系では, PDA 会合体から PDA モノマーへの顾起エネルギ 一移動が観察された。一方, $\mathrm{pH} 9.0$ の水溶液中, 低濃度 $\left(1 \times 10^{-6} \mathrm{~mol} \cdot \mathrm{dm}^{-3}\right)$ 領域では，モノマー状 態で溶解し， $2 \times 10^{-5} \mathrm{~mol} \cdot \mathrm{dm}^{-8}$ 以上の PDA 濃度領域ではミセルを形成した。PDA ミセルは，モ， マー蛍光のみを示し, PDA 会合体からヒノマーへの励起エネルギー移野が進行した。䠦界ミセル浱度 以下の低濃度 PDA 水溶液に， $\mathrm{NaCl}$ を添加すると，無訬光性会合体が生じ，この場合には，PDA モ ノマーから会合体へのエネルギー移動が起こることが，鸴光の励起スペクトルおよび減衰曲線の測定結 果から示唆された。PDAーステフリン酸混合采においては，水一空気界面に単分子膜が形成され，その 累積膜の蛍光スペクトルには，モノマー発光以外に，エキシマー蛍光が観測された。モノマーおよびェ キシマー蛍光ともに, その減衰曲線は多成分的で, 励起エネルギー移動がやはり進行するものと思われ, 累積膜中でる，PDA のピレニル基は，一部不規則な配置をした無蓝光性会合体を形成するものと推諭 される。

\section{1 榰言}

分子生物学の発展と相まって，生体内現象をモデルとした分子 集合体の化学か，近年急速に研究，堋発されるようになってき た。界面活性刜ミ七ルやリン脂筫小胞体（リポソーム）のような， 両親媒性化合物の自己集合体の化学 ${ }^{1)}$ に始まり，最近では，より 高度に設計することができ，機能性材料としての可能性を秘めた Langmuir-Blodgett 膜 (以下 LB 膜と略記する) 2) む゙, 分子集 合体の化学には, 多くの魅力ある砳究対象が存在する。ミセルや リボソームを自己集合体（self assembly）と呼ぶならば，高度な 機能をむたせるべく設計された LB 獏などは，自己組絨体（self organism）といえよ5。自己組織体を杪築するためには，その棈 成単位である分子が単独あるいは集合した場合に，特長ある機能

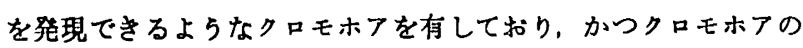
配列をできるたけ自由に制御できる特性を有していなければなら ない。分子組織体を指向した研究の歴史は浅く，用いられるべき 案材の供給も不十分であり，また，その榄合系のキャラクタリゼ ーションや分子配列を制御する因子などの基礎的知見についての 情報にもきわめて乏しい。

本研究では，機能性クロモホアモデルとしてピレニル基を退 同志社大学工学部工業化学科, 602 京都市上京区今出川 通身丸東入

1) J. H. Fendler, "Membrane Mimetic Chemistry", John Wiley and Sons, Inc., New York, N. Y. (1982).

2) 日本化学会編, 福田清成, 中原弘婎著, “化学総説, No. 40, 分子樂合体その組織化と機能”, 学会出版センター (1983) p. 82
び、ピレニル然を有する两親煤性化合物、10-(1ーピレニル)デカ ン酸（以下 PDA と略記する），の水中に扑ける自己会合体の性 質につき娭时した。ピレニル基は，モノマーおよび集合状態か ら、それぞれ潩なった緟光を発するため，分子集合状態のキャラ クタリゼーションを行ならための良好なプローブとなり得る。本 研究は，分子組織体を開発する上での基礎的知見を得ることを目 的として荚施した。

\section{2 実 験}

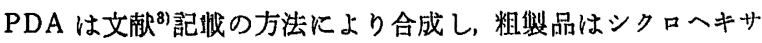
ソークロロホルム混合溶媒から再絬晶し、さらにシリカゲルカラ ムクロマトグラフィー(ヘキサンークロロホルム)により精斐し た。 $\mathrm{mp} 111^{\circ} \mathrm{C}$ 。ヘキサデシルトリメチルアンモニウムニクロリド (以下 HTAC と略記する) 扰よび硫酸ドデシルナトリウム（以下 SDS と略記する) は，それぞれ半井化学社货 1 級お゙よび難溶珄タ ンパク留研究用試薬をそのまま用いた。ステアリン酸（以下 StA と略記する）は市肘特級品（半井化学社製）を用いた。 $\mathrm{pH}$ の設 定には, Britton-Robinson 広域綬衝液 $\left(0.04 \mathrm{~mol} \cdot \mathrm{dm}^{-8}\right)$ を用い た。

PDA の緩政溶液への分散あるいは溶解は，つぎのようにして 行なった。 $5 \mathrm{ml}$ の綬菦溶液に, $1 \times 10^{-8} \mathrm{~mol} \cdot \mathrm{dm}^{-3}$ の PDA メタ ノール溶液の適当泟をマイクロシリンジで加えて分敞後，30 秒 間超音波确射 (50 W 水浴式超音波洗浄装㯰使用) した。このよ らにして作䤜した溶液の吸収および监光スペクトルは，それぞれ

3) H.-J.Galla, W. Hartmann, Methods Enzymol., 72, 471(1981). 
島津 UV-200S 自記分光光度計扰上び日立 650-60 分光蛍光光度 計を用いて， $25^{\circ} \mathrm{C}$ で测定した。陚料の脱酸素は行なわなかった。

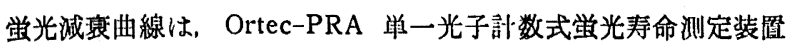
を用いて测定し，得られたデータは，Simplex 法によりコンピュ ーター解析して寿命を炏定した。

\section{3 結 果}

\subsection{PDA の水中での自己会合}

pH 9.0 の Britton-Robinson 楥政溶液 $\left(0.04 \mathrm{~mol} \cdot \mathrm{dm}^{-8}\right)$ 中の PDA $\left(1 \times 10^{-8} \mathrm{~mol} \cdot \mathrm{dm}^{-3}\right)$ の蛍光スペクトルには，図 1 に示すよ らに，375，395，扰び $416 \mathrm{~nm}$ に $\lambda_{\max }$ が認められる。この蛍 光スペクトルは，低濃度の PDA シクロヘキサン均一溶液中のそ れと本留的に一致しており，モノマー発光と結論される。一方， $5 \times 10^{-8} \mathrm{~mol} \cdot \mathrm{dm}^{-8} \mathrm{PDA}$ の $\mathrm{pH} 5.0$ 水溶液中の监光スベクトルに は, 375 および $390 \mathrm{~nm}$ のモノマー発光以外に, 422 および 436

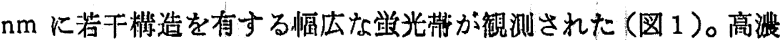
度の PDA シクロヘキサン溶液 $\left(1 \times 10^{-8} \mathrm{~mol} \cdot \mathrm{dm}^{-8}\right)$ は, $464 \mathrm{~nm}$ に槛造のない幅広なエキシマー䖢光を示すため, $\mathrm{pH} 5.0$ 水溶液 中の長波辰侧の蛍光は，face-to-face 形エキシマーに基つくくの とは思われない。さらに特徽的なことは，监光の励起スペクトル に，高 $\mathrm{pH}$ 領城では認められなかったバンドが, $354 \mathrm{~nm}$ に観察 されることである。緟光スペクトルのいずれの極大波長で追跡し ても，その励起スべトルには，354 nm に極大が琶められた。 $\mathrm{pH} 5.0$ の PDA 水溶液の緷光の長波長成分は, PDA 無定形固体 のスペクトルにも钼察される(四 1)。このことから，422 および $436 \mathrm{~nm}$ に極大を有する幅広な緹光带は，水中に分散したミク口 クリスタルから発せられるものと考㝋られる。 $354 \mathrm{~nm}$ の励起ス ペクトルの極大は, PDA ミクロクリスタルの吸収極大に対応す るものと思われ，事夹，励起スペクトルとよく対応した吸収スペ クトルが锶察された。ただし，吸収スペクトルには，360〜500 $\mathrm{nm}$ の領城に，幅広で四光係数の小さな吸収帯が認められた。

つぎに, pH 5.0 綬衙溶液中の PDA 分散系における光化学的 举功につき検討する。さきに述べたように，PDA の励起スペク

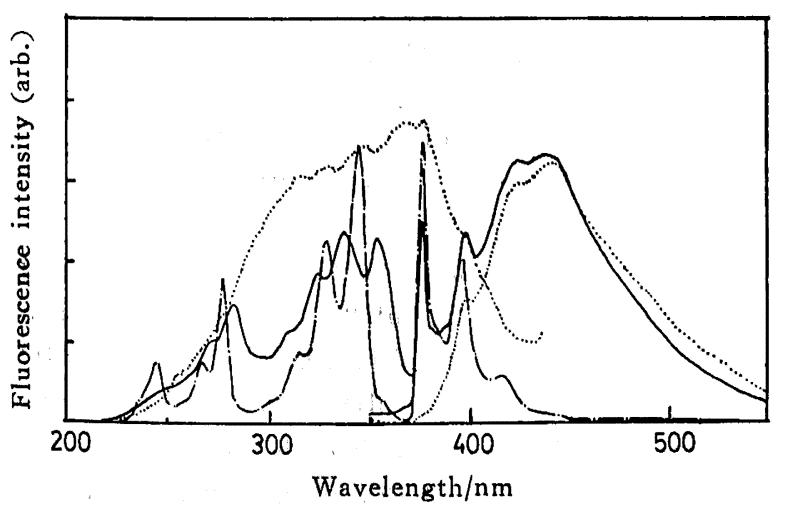

Fig. 1 Fluorescence emission and excitation spectra for PDA in pH $5.0\left(-,[P D A]=5 \times 10^{-8} \mathrm{~mol} \cdot \mathrm{dm}^{-8}\right.$, $\left.\lambda_{\theta \mathrm{x}}=354 \mathrm{~nm}, \lambda_{\theta \mathrm{m}}=375 \mathrm{~nm}\right)$ and $\mathrm{pH} 9.0$ BrittonRobinson buffers $\left(0.04 \mathrm{~mol} \cdot \mathrm{dm}^{-8}\right)(-.$, , [PDA] $\left.=1 \times 10^{-6} \mathrm{~mol} \cdot \mathrm{dm}^{-8}, \quad \lambda_{\mathrm{ex}}=344 \mathrm{~nm}, \quad \lambda_{\mathrm{em}}=375 \mathrm{~nm}\right)$ and for solid PDA $\left(\cdots \cdots, \lambda_{\theta x}=347 \mathrm{~nm}, \lambda_{o \mathrm{~m}}=443\right.$ $\mathrm{nm})$ at $25^{\circ} \mathrm{C}$
トルを，375 nm のモ/マー监光極大で测定しても，また，422 お よび $436 \mathrm{~nm}$ の会合体巣光領域で測定しても，まったく同一のス ペクトルを与えた。さらに，励起スベクトルの極大波畏である 324，337，および $354 \mathrm{~nm}$ で励起して得られたそれぞれの蛍光ス ペクトル間には，まったく相違は認められなかっった。354nm は， 明らかに PDA 会合体の吸収極大波長であるため，かかる波脣で

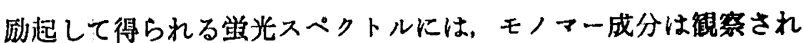
ないものと予想される。しかるに実際には，モノマー発光が怹め られた。また， $375 \mathrm{~nm}$ の蛍光極大は，PDA モノマーに基つくに もかかわらず，この波長で測定した励起スペクトルには, $354 \mathrm{~nm}$ にPDA 会合体による吸収带に対応したバンドが明らかに認めら れた。以上の実験事実は，PDA 分子会合体から、系中にわずか に存在する PDA モノマーへの一重項一重項励起エネルギー移 亜を考虑すると，矛盾なく説明される。Förster 型エネルギー移 䄭が進行するためには, PDA 会合体の蛍光带が, PDA モノマー の四収带と重なる必要がある(1)5) PDA 固体粉末の蛍光スベクト ルから判断して，PDA 会合体の蛍光は，375 nm 以上の波長領域 にあり; 一方, PDA の禁制選移である ${ }^{1} \mathrm{~L}_{\mathrm{b}}$ 吸收带の 0-0 帯は $379 \mathrm{~nm}\left(\varepsilon=4300 \mathrm{~mol}^{-1} \cdot \mathrm{dm}^{2}\right)$ に視测された。重なり碳分はかな ク小さいと予想されるが，会合体近傍に存在する PDA モノマー へのエネルギー移動が，低効家ながら進行するるのと思われる。

\subsection{PDA 自己会合におよぼす $\mathrm{NaCl}$ の湑加奻果}

$\mathrm{pH} 9.0$ 瑷衡溶液中に, 低港度の PDA $\left(1 \times 10^{-6} \mathrm{~mol} \cdot \mathrm{dm}^{-3}\right)$ は モノマー状態で溶解するため，モノマー蛍光のみが観測される。 このよらな系に $\mathrm{NaCl}$ を添加すると， $-\mathrm{COO}^{-}$基の $\mathrm{Na}^{+}$による中 和および塩析の効果により，PDA が会合するるのと予想される。 図 2 に, $1 \times 10^{-6} \mathrm{~mol} \cdot \mathrm{dm}^{-8}$ PDA の pH 9.0 Britton-Robinson 微溶液 $\left(0.04 \mathrm{~mol} \cdot \mathrm{dm}^{-8}\right)$ に $\mathrm{NaCl}$ を添加した場合の蛍光および

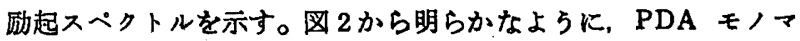
一蛍光は， $\mathrm{NaCl}$ の添加により消光されるが，会合体に基つく新

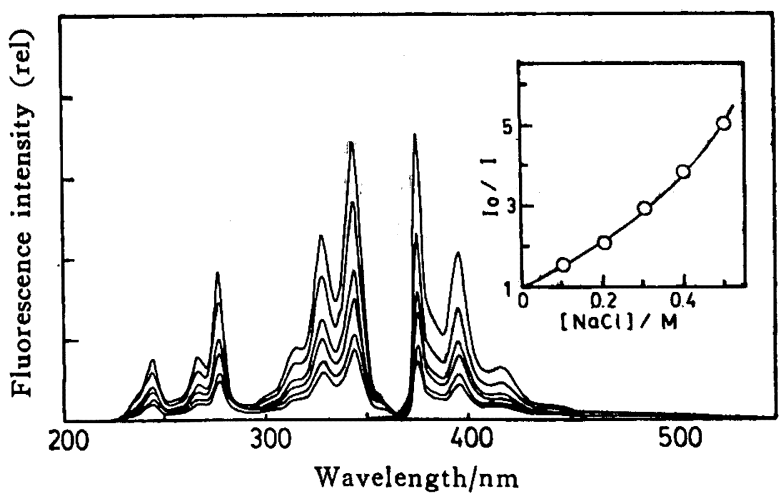

Fig. 2 Fluorescence emission $\left(\lambda_{\mathrm{ax}}=344 \mathrm{~nm}\right)$ and excitation spectra $\left(\lambda_{\theta \mathrm{m}}=375 \mathrm{~nm}\right)$ for PDA $\left(1 \times 10^{-6} \mathrm{~mol}\right.$. $\left.\mathrm{dm}^{-3}\right)$ in $\mathrm{pH} 9.0$ Britton-Robinson buffer (0.04 $\left.\mathrm{mol} \cdot \mathrm{dm}^{-3}\right)$ in the absence and presence of $\mathrm{NaCl}$ $\left([\mathrm{NaCl}]=0,0.1,0.2,0.3,0.4,0.5 \mathrm{~mol} \cdot \mathrm{dm}^{-8}\right.$ from the top) at $25^{\circ} \mathrm{C}$ and the Stern-Volmer plot for the fluorescence quenching of PDA by $\mathrm{NaCl}$ (insert)

4) Th. Förster, Discuss. Faraday Soc., 27, 7(1959).

5）加納䊀治，松尾 拓，化学，35，120(1980), 


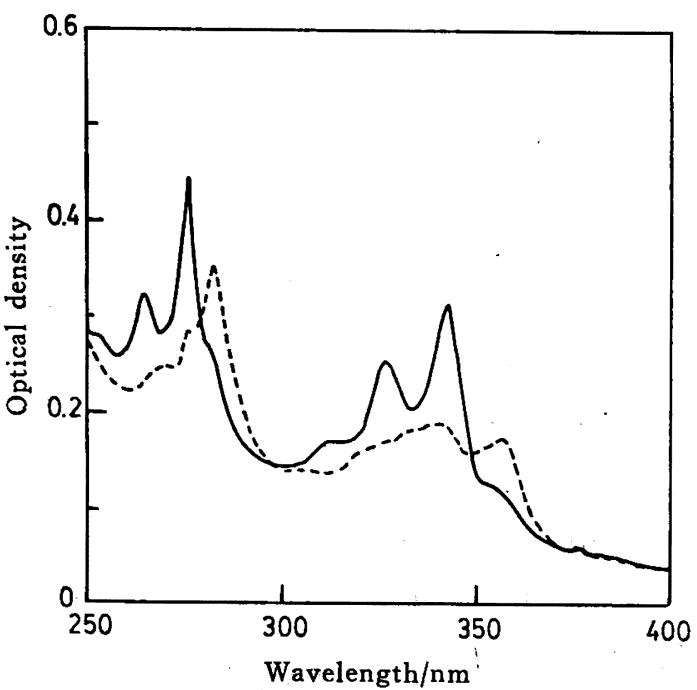

Fig. 3 Absorption spectra of PDA $\left(1 \times 10^{-8} \mathrm{~mol} \cdot \mathrm{dm}^{-8}\right)$ in $\mathrm{pH} 9.0$ Britton-Robinson buffer $\left(0.04 \mathrm{~mol} \cdot \mathrm{dm}^{-3}\right)$ in the absence (-) and presence of $0.5 \mathrm{~mol} \cdot \mathrm{dm}^{-3}$ $\mathrm{NaCl}(--)$ at $25^{\circ} \mathrm{C}$

The spectra were taken by using a quartz cell having a $10 \mathrm{~cm}$ optical length

たな蛍光はまったく認められなかった。また，励起スペクトルす， 強度低下以外飞何ら变化は観察されなかった。しかし, PDAの 吸収スベクトルは，四3に示すように， NaCl 添加炕より大きく 变化した。すなわち, $\mathrm{NaCl}$ 不在下にくらべ, $0.5 \mathrm{~mol} \cdot \mathrm{dm}^{-8}$ の $\mathrm{NaCl}$ 存在下の PDA '吸収スペクトルは，ピレニル基に基らくく ${ }^{1} \mathrm{~L}_{\mathrm{a}}$ および ${ }^{1} \mathrm{~B}_{\mathrm{b}}$ 帯が長波長側ヘシフトし，かつ幅広くなった。明 らかに， NaCl の添加により，PDA の会合が進行することがわか る。一方, 图2 中に示すように, PDA 蛍光強度に関する SternVolmer プロットは直線にはならず，上向きに曲がった曲線とな った。四4 亿, PDA モノマー蛍光減衰曲線に打よ仿す $\mathrm{NaCl}$ の 効果を示す。 $\mathrm{NaCl}$ 不在下に扰いても，PDA モノマー蛍光は，指 数関数的に法减衰せず，見かけ上二成分 $\left(\tau_{1}=5.8 \mathrm{~ns}(36 \%) ， \tau_{2}\right.$ $=85.0 \mathrm{~ns}(64 \%))$ となった。 $\mathrm{NaCl}$ を添加すると, 速い减衰の割 合いが增加した。長寿命成分の寿命はほとんど変化せず，86〜89 ns であっだ。これらの結果は，PDA の $\mathrm{NaCl}$ による蛍光消光 が， $\mathrm{Cl}^{-}$に上る動的消光あるいは無蛍光性 PDA 会合体形成に上 る静的消光のいずれによっても説明できない。お゙そらく， $\mathrm{NaCl}$ の添加により，無鉴光性会合体加形成され，この会合体へ，PDA モノマーからの励起エネルギー移動が進行するるのと思われる。

\subsection{PDA ミセルの形成}

PDA は両親媒泩分子であるため, フルカリ水溶液中でミセル を形成する可能性がある。そこで， pH 9.0 Britton-Robinson 緩 衝溶液 $\left(0.04 \mathrm{~mol} \cdot \mathrm{dm}^{-8}\right)$ 中の PDA の営光スペクトルを, PDA 浔度を変化させて測定した（因 5 )。いずれの PDA 濃度に打い ても，344 nm で励起して得られる蛍光スペクトルは，PDAモノ マーに基つくるのであり，エキシマーや会合体による蛍光は，ほ とんど認められなかった。ところが, $375 \mathrm{~nm}$ の PDA モノマー 蛍光の極大波長で測定した励起スペクトルの各バンドは，PDA 浱度の增加とともに頭著に幅広くなり,さらに $356 \mathrm{~nm}$ に新たな 極大が認められるようになった。罡収スペクトルにおいても。
Channel number

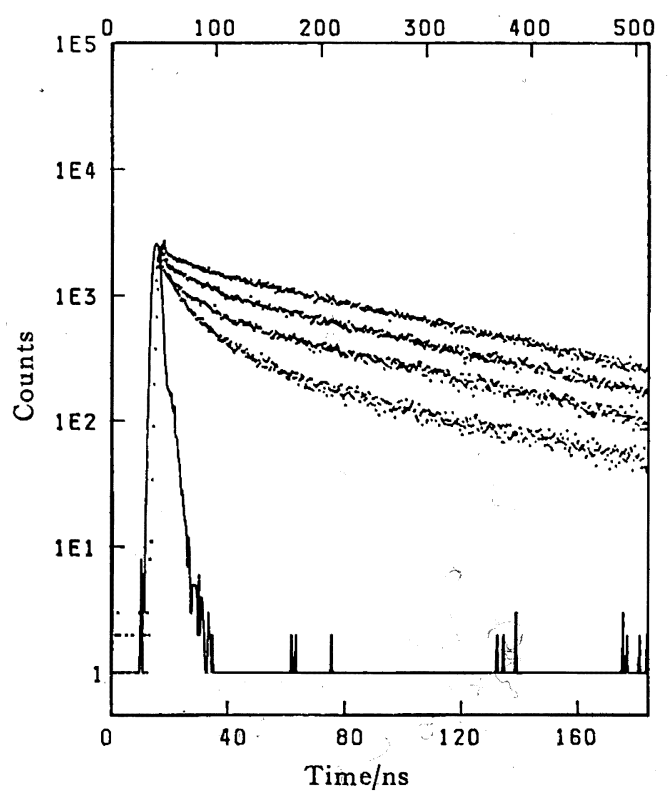

Fig. 4 Fluorescence decay curves for PDA $\left(1 \times 10^{-\theta}\right.$ $\mathrm{mol} \cdot \mathrm{dm}^{-3}$ ) in $\mathrm{pH} 9.0$ Britton-Robinson buffer $\left(0.04 \mathrm{~mol} \cdot \mathrm{dm}^{-3}\right)$ in the absence and presence of $\mathrm{NaCl}\left([\mathrm{NaCl}]=0,0.1,0.2,0.5 \mathrm{~mol} \cdot \mathrm{dm}^{-8}\right.$ from the top) at room temperature

PDA was excited at $327 \mathrm{~nm}$ and the emission was followed by passing through a Toshiba UV-35 filter

PDA 濃度の増加にともなって幅広くなり，358 nm の新たな吸収 帯の出現が観察された。 $358 \mathrm{~nm}$ の四収帯は，励起スペクトルの $356 \mathrm{~nm}$ のバンドに対応し， $2 \mathrm{~nm}$ のずれは，発光スペクトルが末 補正なためと思われる。この励起扰よび吸収ズペクトルの変化 は，明らか飞 PDA 漫度の增加にともなら PDA 会合体の生成を 示している。 $356 \mathrm{~nm}$ の励起スペクトルの極大は, PDA 会合体に 基づくものと思われる。しかるに，344 お上び $356 \mathrm{~nm}$ のいずれ の波長で励起した場合にも，PDA モノマーに基つくく蛍光スペク トルしか観察されなかった。このことから、比較的高濃度のPDA 水溶液中では, 無喾光性の PDA 会合体からモノマーへの贸起工 ネルギー移動が進行するるのと考兄られる。このエネルギー移動 の挙動は，さきに述べた $\mathrm{NaCl}$ を含む低濃度 PDA 水溶液中の場 合とは逆であり，両者で巽なった種類の PDA 会合体が生ずるる のといえる。

図 6 に，356 および $344 \mathrm{~nm}$ で励起した場合の $375 \mathrm{~nm}$ そ批け る蛍光強度比 $\left(I_{356} / I_{344}\right)$ および $\mathrm{pH} 9.0$ の PDA 水溶液の表面張 力に対する PDA 濃度の影響を示す。表面張力の測定から，PDA の Britton-Robinson 緩衝溶液 $\left(\mathrm{pH} \mathrm{9.0}, 0.04 \mathrm{~mol} \cdot \mathrm{dm}^{-8}\right)$ 中K 拈ける臨界 ミセル浱度 $(\mathrm{cmc})$ は, 約 $2 \times 10^{-5} \mathrm{~mol} \cdot \mathrm{dm}^{-3}$ と見積ら れ，をた $\mathrm{cmc}$ 以上の PDA 浱度で， $I_{356} / I_{344}$ の值は，一定値に近 つく傾向が見られた。

PDA はミセルを形成することにより，その蛍光寿命がいちし るしく短くなった（因7）。さきに述べたよ $\mathrm{dm}^{-8} \mathrm{PDA}$ 水溶液 ( $\mathrm{pH}$ 9.0) の巣光寿命は，二成分から成ってい る $\left(\tau_{1}=5.8 \mathrm{~ns}, \tau_{2}=85.0 \mathrm{~ns}\right)$ 。 ところが, $\mathrm{cmc}$ 以上の PDA 水溶 液に対して得られる寿命は， $\tau_{1}=5.8 \mathrm{~ns}(86 \%)$ および $\tau_{2}=19.1$ 


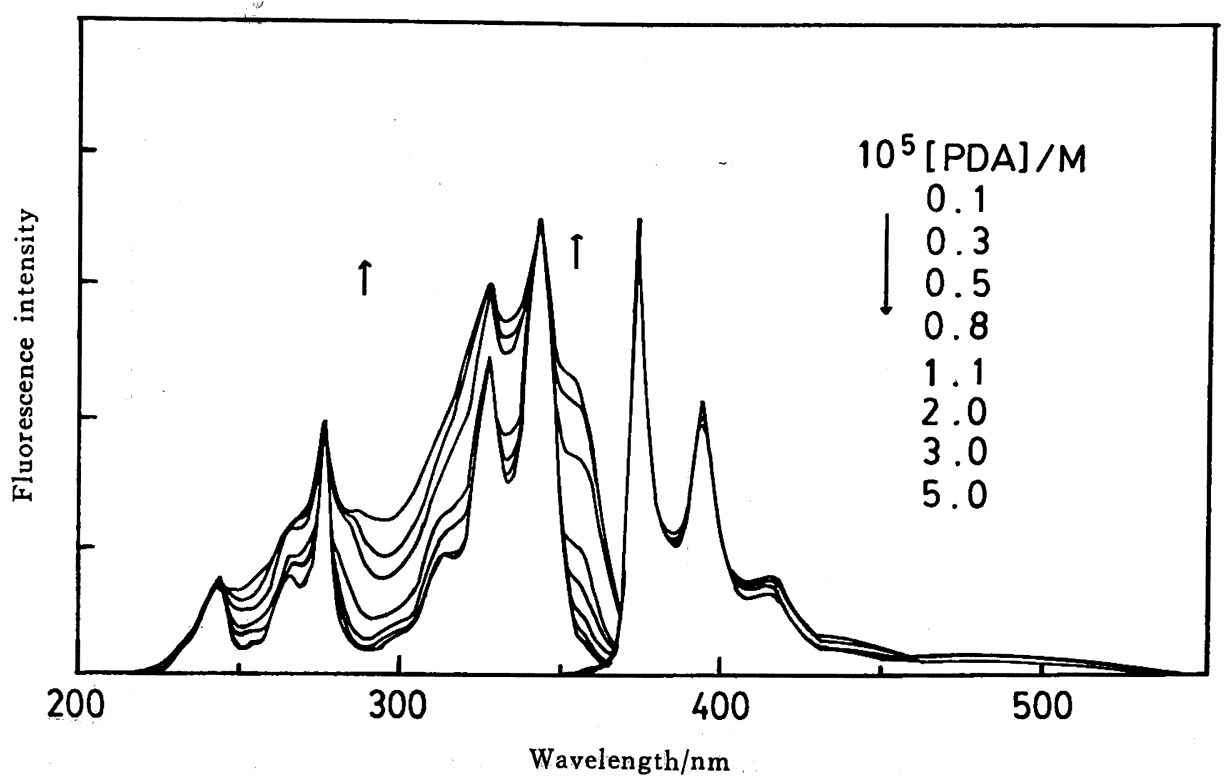

Fig. 5 Normalized fluorescence emission and excitation spectra of various concentrations of PDA in $\mathrm{pH} 9.0$ Britton-Robinson buffer $\left(0.04 \mathrm{~mol} \cdot \mathrm{dm}^{-3}\right)$ at $25^{\circ} \mathrm{C}\left(\lambda_{\mathrm{ex}}=344 \mathrm{~nm}, \lambda_{\mathrm{em}}=375 \mathrm{~nm}\right)$

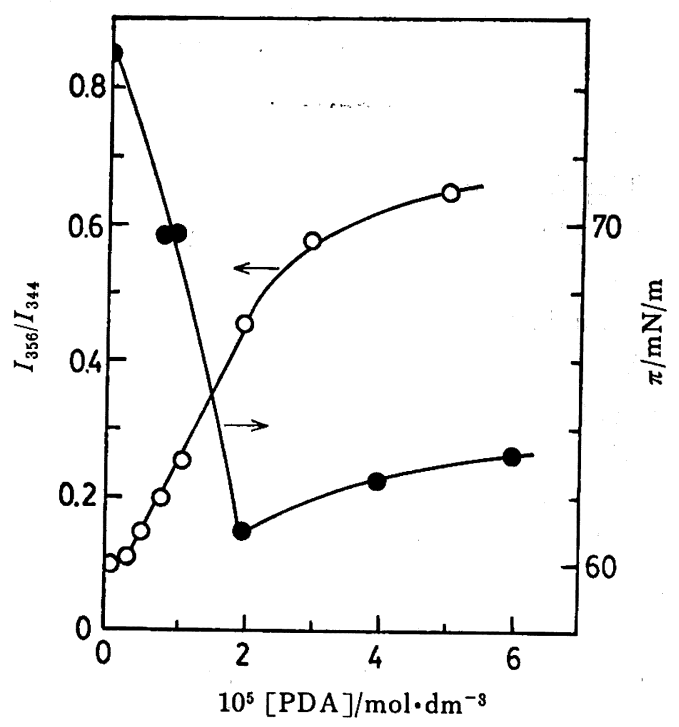

Fig. 6 Plots of the ratio of the fluorescence intensities at $375 \mathrm{~nm}$ of PDA excited at 356 and $344 \mathrm{~nm}\left(I_{856}\right)$ $\left.I_{344}\right)$ and the surface tension $(\pi)$ vs. PDA concentration

The $\mathrm{pH} 9.0$ Britton-Robinson buffer $\left(0.04 \mathrm{~mol} \cdot \mathrm{dm}^{-3}\right)$ was used as a solvent

ns (14\%) となり，短寿命成分が増加し，また長寿命成分も 85.0 ns から $19.1 \mathrm{~ns}$ へといらじるしく短くなった。

cmc 以下の PDA 濃度に拈いても, 蛍光減衰が単一指数関数と はならず，二成分の寿命が存在するのは，PDA が低濃度領域に おいても小さな会合体（前期ミセル）帛形成するためたと思わ

6) たとえば, H. Sato, M. Kawasaki, K. Kasatani, Y. Kusumoto, N. Nakashima, K. Yoshihara, Chem. Lett., 1980, 1529,
れる。PDAをSDS や HTAC ミセルに取込ませた場合には, $136 \mathrm{~ns}$ の寿命を示す単一指数関数的減衰が観察された。

\subsection{PDA の LB 膜}

以上の結果から，水中において PDA は種々の会合体を形成す ることがわかったが，これらの会合体は，ピレニル基が face-toface 形に規則正しい配列をした場合に発するエキシマー蛍光を 示さなかった。そこで最後に, PDA 分子を, 水一空気界面に単分 子膜として配列させ，その累積膜の蛍光分析から，単分子膜中の ピレニル基の配置につき検討した。

サブフェーズに $1 \times 10^{-4} \mathrm{~mol} \cdot \mathrm{dm}^{-9} \mathrm{CaCO}_{3}$ 水溶液 $(\mathrm{pH}$ 6.0) を 用いた PDA 単独怙よび PDA: StA=1:12 (モル比) 湦合系の $\pi-\mathrm{A}$ 曲線の測定 $\left(20^{\circ} \mathrm{C}\right)$ から, PDA 単独では安定な凝縮膜を得 ることができないが，StA との混合系では凝樎膜を形成できるこ とがわかった。そこでこの混合系を用いて，表面圧を $16 \mathrm{mN} / \mathrm{m}$ と一定にし，累積膜 ( $\mathrm{Y}$ 膜, 40 層) を作製した。このようにして 得られた LB 膜の蛍光スペクトルを図 8 に示す。Yamazaki ら゙ が, 16-(1-ピレニル)へキサデカン酸 (以下 PHDA と略記する)StA 混合系の LB 膜について観測したのと同様, PDA LB 膜に おいても，470 nm 付近に $\lambda_{\max }$ を有するエキシマー様蛍光が認 められた。同様条件下、Y膜を 30 層累積した LB 膜に関して。 モノマーおよび会合体蛍光の隇衰曲線を測定し、結果を図 9 に示 す。モノマー蛍光は, 見かけ上 3 成分に分けられ, 光散乱成分を 除くと, $\tau_{1}=4.1 \mathrm{~ns}(78.1 \%), \tau_{2}=20.7 \mathrm{~ns}(13.6 \%)$ ，および $\tau_{3}$ $=143.4 \mathrm{~ns}(8.3 \%)$ と求まった。一方，エキシマー様蛍光も，少 くとも三成分あり， $\tau_{1}=5.8 \mathrm{~ns}(65.6 \%), \tau_{2}=30.2 \mathrm{~ns}(18.8 \%)$, および $\tau_{3}=81.5 \mathrm{~ns}(15.6 \%)$ となった。また著者らの用いた装置 では, エキシマー様蛍光の立ち上がりを測定することができなか った。モノマーおよびェキシマー蛍光ともに, 多成分的減哀を示 すことから，LB 膜中にエネルギートラッブが存在するものと考

7) T. Yamazaki, N. Tamai, I. Yamazaki, Chem. Phys, Lett., 124, 326(1986). 

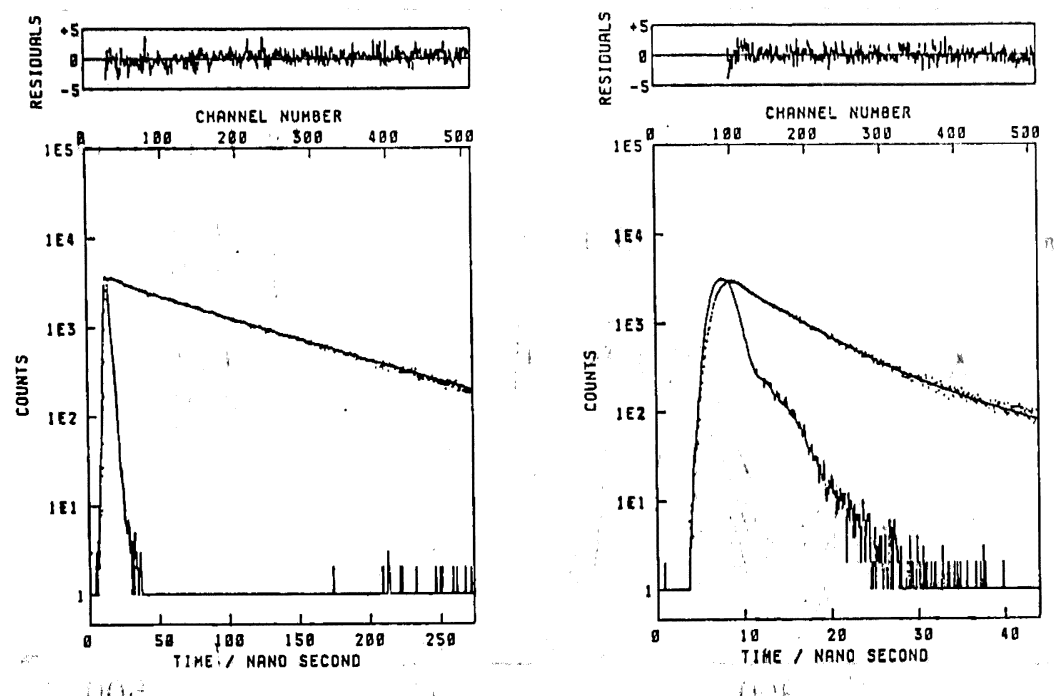

Fig. 7 Fluorescence decay curves for $1 \times 10^{-6} \mathrm{~mol} \cdot \mathrm{dm}^{-8}$ (left, $\lambda_{0 \mathrm{x}}=314 \mathrm{~nm}, \lambda_{\mathrm{om}}=396 \mathrm{~nm}$ ) and $6 \times 10^{-8} \mathrm{~mol} \cdot \mathrm{dm}^{-8}$ PDA (right, $\lambda_{e x}=320 \mathrm{~nm}, \lambda_{0 \mathrm{~m}}=378 \mathrm{~nm}$ ) in $\mathrm{pH} 9.0$ buffer solutions at room temperature

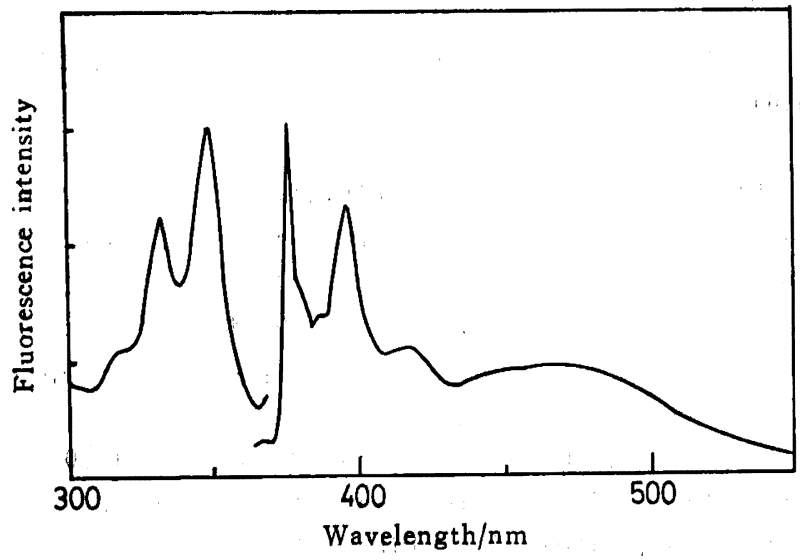

Fig. 8 Fluorescence emission and excitation spectra $\left(\lambda_{e x}=349 \mathrm{~nm}, \lambda_{e m}=375 \mathrm{~nm}\right.$ ) for a Langmuir-Blodgett membrane composed of PDA and stearic acid ( $1: 12$ molar ratio)

The subphase was aqueous $1 \times 10^{-4} \mathrm{~mol} \cdot \mathrm{dm}^{-8} \mathrm{CaCO}_{3}$ and 40 layers ( $Y$-type) were transferred onto a nonfluorescent glass plate

えられる。

\section{4 考察}

末端にピレニル基を有する离級脂肪酸は，従来：ミセルやリポ ソームの粠造，流動性，極性，リポソーム間枟移などの研究用プ

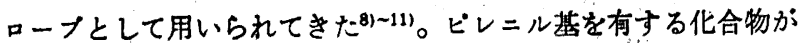
蛍光プローフとして用いられる理由として，1）モ/マーと励退

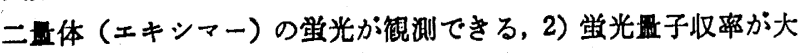

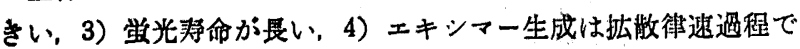
ある，5）ビレンモノマーの蛍光は媒体の梫性に微感であるなど

8) J. Luisetti, H. Möhwald, H.-J. Galla, Biochim. Bio. phys. Acta, 552, 519(1979).
が等げられる。ミセルやリポソーム，あるいは高分子のよらな, 溶液中で比胶的ゆらいだ满造を有する分子会合体中のピレンクロ モホアは，モノマーおよび face-to-face 形配阴のエキシマー爯光 のみを示す。これらの吥宪とは独立に，最近では，浇能性分子㷛 合体（分子組䄉体）に関する甚礎研究として，两親煤性ピレン化 合物の自己会合体についても梌期され始めている。

Mitsuya ら ${ }^{18)}$ は, 12-(1-ピレニル)ドデカン酸（以下 PDDA と

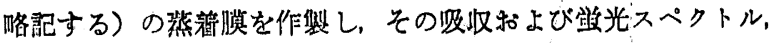

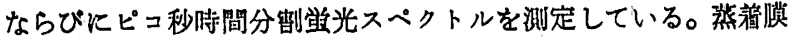
の吸収スペクトル上には，359 nm に PDDA の自己会合体に甚 つく吸収带が推测され，さらに篮光スペクトルにはーヒノマー监光 は喼められず，423，448，478，扰よび $510 \mathrm{~nm}$ に会合体に造つく

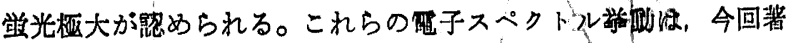
者らが pH 5.0 㖟衍溶液中の PDA 分散系に対して得た結果に一 部類似している。すなわち PDA 分敉水溶液系でけ, $354 \mathrm{~nm}$ に PDA 会合体に甚つく吸収带が存在し，また，422 拈よび $436 \mathrm{~nm}$

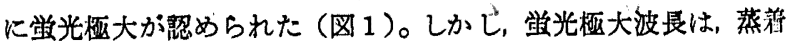
膜と分敬系とではかなり舅なって拈り，舅なった形热の会合伖が

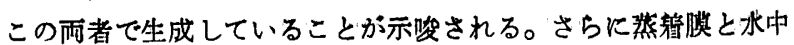
の分牧系とでは，これらの会合体中で進行する光化学的過程に相

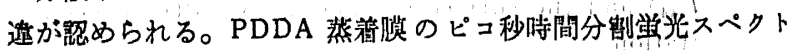
ルでは、レーザーパルス照射後 0〜200ps の間にはピレンモノマ

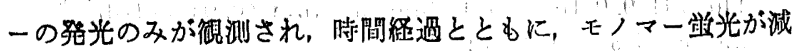

9) H.-J.Galla, U. Theilen, W. Hartmann, Chem. Phys. Lipids, 23, 239(1979).

10) K. Kano, H. Kawazumi, T. Ogawa, J. Sunamoto, $J$. Phys. Chem., 85, 2204(1981).

11) K. A. Zachariasse, B. Kozankiewicz, W. Kühle, "Surfactants in Solution", Vol.1, K. L. Mittal, B. Lindaman ed, Plenum Publishing Co., New York, N. Y. (1984) p. 565.

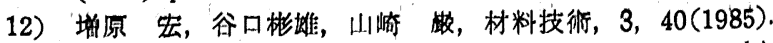

13) M. Mitsuya, Y. Taniguchi, N. Tamai, I. Yamazaki, H. Masuhara, Thin Solid Films, 129, I, 45(1985). 

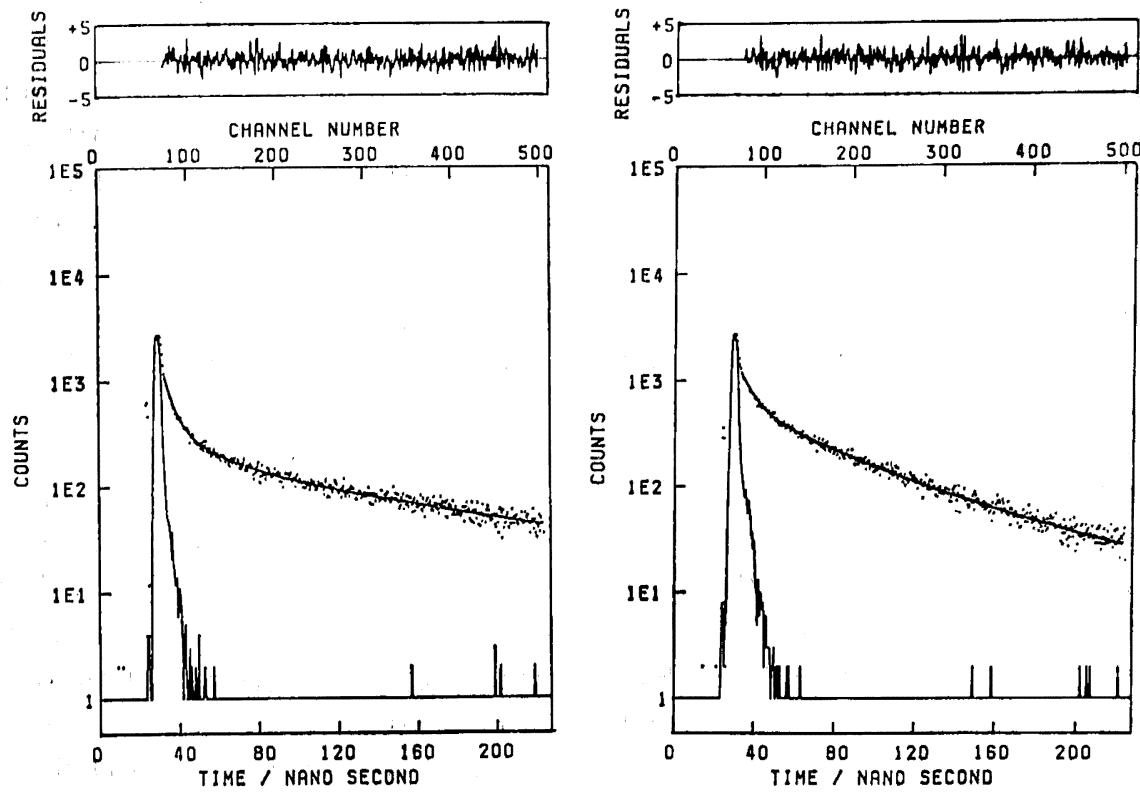

Fig. 9 Decay curves for the PDA monomer (left, $\lambda_{0 x}=333 \mathrm{~nm}, \lambda_{\mathrm{om}}=385 \mathrm{~nm}$ ) and excimer-like fluorescence (right, $\lambda_{o x}=333 \mathrm{~nm}, \lambda_{\theta \mathrm{m}}=470 \mathrm{~nm}$ ) for a LangmuirBlodgett membrane (30 layers) composed of PDA and stearic acid (1:12 molar ratio)

衰し，会合体鲕光の溞度が增大してくる。Mitsuya らは，この实 験結果を, PDDA モノマー状熊から会合体への励起エネルギー゙ 移皿を考えることにより説明している18)。しかし，PDA の水へ の分散系では，近に PDA 会合体からヒノマー状热へのエネルギ

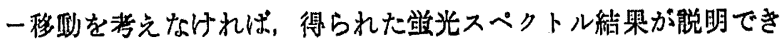
なかった（3.1 参照）。 pH 5.0 の水中に分敬したPDA 会合体の 単光スペクトルは, PDA 粉末圆体のそれにきわめて類似してい

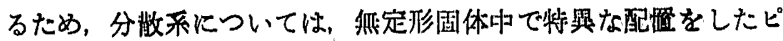
レニル拈からの発光と見なすことができる。最近，PDA 䌽着膜 の签光スペクトルが测定された して，420，450，480，抢よび $520 \mathrm{~nm}$ に学光極大が観测された

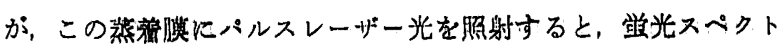

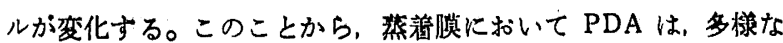
漼安定会合状熊を形成するものと思われる。

水㴼液系に打いても，条件の邀いにより，多棣なPDA 会合体 が形成されることが，今回の荚験から明らかとなった。 pH 5.0

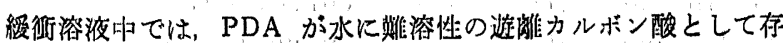
在するため，ミクロクリスタル状热で分散する。系の $\mathrm{pH}$ を占 ると（pH 9.0)，カルボン酸のイオン解截にともない, PDA が水 に溶仍し，この系からはモノマー単光の多が琶められた（四1）。 PDA は，pH 9.0 の緩衍溶液中でミヒルを形成し得る $(\mathrm{cmc}=2$ $\left.\times 10^{-8} \mathrm{~mol} \cdot \mathrm{dm}^{-8}\right)$ 。予想に反して，PDA はミヒルを形成しても

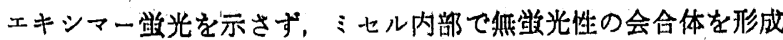
する。ミセルの楼造が球状だ仮定すると，ピレニル甚はミセル 内部に滥縮されるはずである。このPDA ミセル会合体の光化学

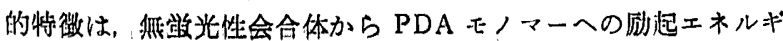

14) A.Itaya, T. Kawamura, H. Masuhara, Y. Taniguchi, M. Mitsuya, H. Uraki, K. Kano, S. Hashimoto, Chem. Lett., 1986, 1541.

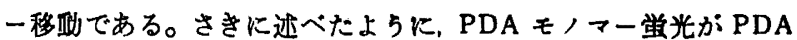
会合体のみを姫起しても钼测されたことから、この栢のエネルギ 一移勁が侾えられた。おそらく，PDA ミセル内には無蛍光 PDA 会合体のごく近偣に，ピレニル基がモノマーとして存在し得る領 城が存在するものと洘えられる。また，PDA ミセル系では， PDA モノマーの蛍光寿命がいちじるしく短くなる（図7）。この ことから，エネルギーを受容した PDA モノマーから，さらに何 らかのエネルギートラップ（別の形態の PDA 会合体と思われ る）へとエネルギー移㽖するものと考えられる。PDA ミ 七ル内 では，ピレニル甚同士が face-to-face 形の配疄を取り得ず，かな り不規則な配列をした会合体が形成されているものと思われる。

$\mathrm{cmc}$ 以下の PDA 峘度 $\left(1 \times 10^{-6} \mathrm{~mol} \cdot \mathrm{dm}^{-8}\right)$ の $\mathrm{pH} 9.0$ 緅微溶 液に $\mathrm{NaCl}$ を添加しても，PDA 会合体が生成した。たたしこ の会合体の光化学的举政は，PDA ミセル会合体とはまったく異 なる(図 2 扰よび 4 参煩)。つまり， $\mathrm{NaCl}$ 存在下に生ずる PDA 会合体系では, PDA モノマーから無算光性のPDA 会合体への エネルギー移旣が進行するため，PDA モノマー噔光が消光され た（3.2 参照）。会合の機槛としては，-COO- の $\mathrm{Na}^{+}$による中 和と醏析效果による PDAの水に対する溶解性の低下が考えられ る。 $-\mathrm{COO}^{-}$の部分的中和が，低 $\mathrm{pH}$ 侧の PDA 会合体や高 $\mathrm{pH}$ 頒城のPDA ミ七ルとは異なる会合形態をとる原因と考えられ る。

以上述べた，いずれの PDA 水溶液系に打いても，PDA 会合 佈から，face-to-face 形のエキシマー棣监光は很察されなかっ た。つまりいずれの物合においても，基底状態におけるビレニル 些の配列は不覞則であり；光励起後もピレニル基の再配列が進行 できるよな環境にないことが明らかとなった。ピレン環は $16 \pi$ 能子系であるか，PDA 会合体中で規則正しい配磁を取り得るは

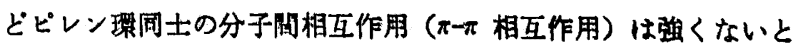


結淪される。

今回行なった実験では，ピレニル基の比較的規則正しい配列 か，LB 膜においてのみ実現できた。PHDA-StA 混合系の LB 膜7)よび PDA-リン脂質混合系の単分子膜 ${ }^{15)}$ の緷光分光学的研 究がすでに報告されている。Yamazaki ら゙は，PHDA-StA 混合 系の LB 膜について，ピコ秒時間分割监光スペクトルを测定し， 1）基底状態ダイマー䖢光 $\left(\lambda_{\max }=381,401\right.$ ，および $\left.422 \mathrm{~nm}\right)$, 2) エキシマー蛍光 $(470 \mathrm{~nm}), 3)$ モノマー蛍光 (377, 397, お。 よび $421 \mathrm{~nm})$, および 4) 新しいタイプのエキシマー蛍光 (420 $\mathrm{nm})$ の 4 種類の蛍光に分類できると報告している。著者らの作 製した PDA-StA 混合系の LB 膜では，定常光励起紗光スペクト

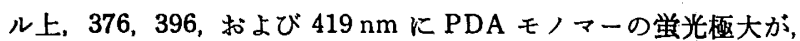
また $470 \mathrm{~nm}$ にエキシマー蛍光極大が钼测され, Yamazaki らの 結果とよく対応している。LB 膜中の PDA モノマー蛍光は，見 かけ上三成分に分けられた $(4.1,20.7$ ，および $143.7 \mathrm{~ns}) 。 143.7$ ns の成分は，LB膜中に孤立して存在する PDA モノマー状態に 基つくくものと思われるが，この成分は，全モノマー蛍光成分の約 8\%にすぎなかった。ほかの短寿命成分は，おそらく，LB 膜中に

15) R. Subramanian, L. K. Patterson, J. Am. Chem. Soc., 107, 5820(1985).
存在する PDA 無蛍光性会合体への励起エネルギー移動に基つく ものと思われる。一方，エキシマー蛍光も，見かけ上三成分に分 けられた $(5.8,30.2$, およよ゙ $81.5 \mathrm{~ns})$ 。今回, エキシマー蛍光の 立ち上がりは観测できなかった。それゆえ，PDA エキシマーが ルーズな基底状態ダイマーから生成するものか，あるいは基底状 態会合体が光励起直後に，ピレニル基の立体配直の再配向なし に、エキシマー蛍光を発するのかは明らかではないが、いずれに せよ，すでに基底状態において二つ以上のピレニル基が face-toface 形に隣接して存在していることは明らかである。長寿命成分 $\left(\tau_{3}=81.5 \mathrm{~ns}\right)$ は, 孤立した光励起ダイマーによるむのと推定さ れるが，モノマー蛍光と同様に，かなりの割合い(約 84\%) で短 寿命成分が存在した。やはりエネルギートラップへのエネルギー 移動が進行するものと考えられた。このように, LB 膜について， 定常光励起监光スペクトルからは，均一溶液中によく似たモノマ 一拈よび face-to-face 形エキシマー蛍光が钼測されたが，これら 以外に，無蛍光性の会合体も共存しているものと思われる。PDA 分子は眯水性アルキル基の末端にピレニル基が結合しているた め, 水一空気界面に形成される単分子膜中のピレン環の配列はか なり乱れる可能性がある。さらによく設計された分子について検 討する必要があろら。

\title{
Special Articles on Molecular Recognition and Its Application
}

\author{
Various Self Assemblies of 10-(1-Pyrenyl) decanoic Acid \\ Koji KANo*, Hisashi URAKI and Shizunobu HASHImoto \\ Department of Applied Chemistry, Faculty of Engineering, Doshisha University; \\ Kamikyo-ku, Kyoto-shi 602 Japan
}

Self assemblies of 10-(1-pyrenyl)decanoic acid (PDA) have been studied by fluorescence spectroscopy. In a pH 5.0 buffer solution, PDA showed both monomer and aggregate fluorescence emissions (Fig. 1). A fluorescence excitation band due to the PDA aggregate was observed at $354 \mathrm{~nm}$ even when the spectrum was recorded at a monomer emission wavelength, indicating the occurrence of energy transfer from the aggregate(s) to the monomer. At higher $\mathrm{pH}, \mathrm{PDA}$ was dissolved in water giving the monomer emission (Fig. 1), and formed micelles at concentrations above $2 \times 10^{-5} \mathrm{~mol} \cdot \mathrm{dm}^{-3}$ (Figs. 5 and 6). Fluorescence excitation spectra (Fig.5) as well as the fluorescence decay curves (Fig.7) suggest the occurrence of energy transfer from the aggregate(s) to the monomer and from the monomer to the nonfluorescent energy trap(s) in the PDA micelles. Below the cmc, PDA molecules also aggregated spontaneously upon addition of $\mathrm{NaCl}$ resulting in fluorescence quenching of $\mathrm{PDA}$ by $\mathrm{NaCl}$ (Fig. 2). The fluorescence decay curves were composed of fast and slow components (Fig. 4). This result as well as those of the fluorescence spectral measurements indicates that energies transferred from the PDA monomer to the nonfluorescent PDA aggregates. An excimer-like fluorescence of PDA was observed for a Langmuir-Blodgett membrane composed of PDA and stearic acid (1:12 molar ratio) at around $470 \mathrm{~nm}$ (Fig. 8). Both monomer and excimer-like emissions decayed multiexponentially (Fig. 9), indicating the occurrence of energy transfer from the monomer and excimer-like states to the nonfluorescent energy $\operatorname{trap}(\mathrm{s})$. An intermolecular $\pi-\pi$ interaction between the pyrenyl moieties of PDA seems to be too weak to organize the PDA molecules regularly in water and the position of the pyrenyl moiety in the PDA molecule is not adequate for forming well-organized LB membranes. 